\title{
Ticodendron incognitum and Neea pittieri associated ectomycorrhizal fungi in Neotropical mountain forest
}

\author{
Põlme S \\ ${ }^{1}$ Natural History Museum of Tartu University, Vanemuise 46, 50410, Tartu, Estonia \\ ${ }^{2}$ Faculty of Science and Technology, Institute of Ecology and Earth Sciences, Department of Botany, Lai 40, Tartu, \\ Estonia
}

Põlme S 2018 - Ticodendron incognitum and Neea pittieri associated ectomycorrhizal fungi in Neotropical mountain forest. Asian Journal of Mycology 1(1), 137-145, Doi 10.5943/ajom/1/1/11

\begin{abstract}
Mycorrhizal associations have crucial importance in the ecology of the majority of terrestrial plants. However, information about mycorrhizal associations of multiple exotic plant taxa remains scant. In order to verify the recently described Ticodenrum incognitum (Ticodendraceae) ectomycorrhizal status I performed root sampling of 15 individuals in Alberto Manuel Brenes Nature Reserve, Costa Rica. For a better description of the local ectomycorrhizal species pool and for estimating potential host preference I sampled adjacent Neea pittieri individuals for putative ectomycorrhizal status. Results confirmed that Ticodenrum incognitum forms ectomycorrhiza with tomentella-thelephora and boletus lineages. In spite of overall scarce ectomycorrhizal associations, comparison of ectomycorrhizal communities of adjacent host species showed clear host preferences.
\end{abstract}

Key words - ectomycorrhizal - host abundance theory - host preference - Ticodendraceae

\section{Introduction}

Understanding the mycorrhizal root traits of plants is critical in understanding ecosystem processes from landscape to global scale, but information about the mycorrhizal status is scant for multiple plant groups. The majority of the mycorrhizal studies were conducted in temperate regions and tropical taxa remain often understudied as compared to their temperate relatives. In spite of "latitudinal bias" the evidence suggests that arbuscular mycorrhiza is the predominant mycorrhizal type in tropical forests (St John \& Uhl 1983, Béreau \& Garbaye 1994, Onguene \& Kuyper 2001, St John 1980, McGuire 2007). Nevertheless, ectomycorrhizal (EcM) associations have been recognized in all major tropical regions involving a high variety of obligately mutualistic fungal and host taxa with independent evolutionary origins (Becker 1983, Connell \& Lowman 1989, Hart et al. 1989, Henkel 2003). In the Neotropics, EcM associations of Pakaraimaea (Dipterocarpaceae), Quercus (Fagaceae), Coccoloba (Polygonaceae), Aldina (Fabaceae subfamily Papilionoideae), Dicymbe (Fabaceae subfamily Caesalpinioideae), Gnetum (Gnetaceae), Neea (Nyctaginaceae), Guapira (Nyctaginaceae), Oreomunnea (Juglandaceae) have been characterized to various degrees, and exhibit a high variation in diversity and host preference (Henkel et al. 2002, Henkel 2003, Morris et al. 2009, Smith et al. 2011,2013, Tedersoo et al. 2010, Moyersoen 2006, Corrales et al. 2016, Séne et al. 2015, Põlme et al. 2017).

Recently described Ticodendron incognitum Gómez-Laur. and L.D. Gómez (Gómez-Laurito 
\& Gómez 1989) from Mesoamerica Atlantic slope forests is the only extant species in Ticodendraceae family (Fagales). In spite of its wide presence in wet mid-elevation forests, these habitats were hard to access until recently and this species were overlooked by the scientific community due to its "ordinary" alder appearance (Hammel \& Burger 1991). Initially the species was described from Costa Rica, but further research expanded its distribution to southern Mexico and Panama. Fossil records from the Eocene suggest that this family was widely distributed in North America and Europe (Manchester 2011). As Fagales comprises predominantly EcM hosting taxa it has been proposed that the EcM habit is ancestral to the whole group (Tedersoo \& Brundett 2017). The EcM habit are characteristic to the majority of Betulaceae and Casuarinaceae taxa which are sister groups to Ticodendraceae (Larson-Johnson 2016). Confirmation of T. incognitum $\mathrm{EcM}$ status would indicate that these families might have had common EcM ancestor, especially when considering temperate history of Ticodendraceae. In spite of these evolutionary implications of the possible EcM habit in T. incognitum, there is no documented record of the mycorrhizal status of this species. The only published study about $T$. incognitum rhizoplane described the new endophytic genus Ticogloea (Weber et al. 1994). To the best of my knowledge, T. incognitum mycorrhizal associations have not been clearly verified, although A. Corrales reported from Panama the non-ectomycorrhizal status (pers. comm.).

In order to ascertain Ticodendron incognito mycorrhizal status I performed root sampling in Costa Rica cloud forest, applying a combination of anatomical and morphological evidence. For better characterization of the local EcM fungal species pool and to asses possible host preference, I collected root samples from neighboring Neea pittieri (Nyctaginaceae) individuals with putative EcM status (Tedersoo et al. 2010). Based on its phylogenetic position I hypothesized that Ticodendron incognitum forms ectomycorrhizal associations.

\section{Material and methods}

\section{Sampling design}

Sampling was performed in Alberto Manuel Brenes Nature Reserve (10.211015, 84.596265), Costa Rica. The mountainous sampling area was covered by pristine neotropical forest situating between 900 and 1200 meters above sea level. The area receives $4000 \mathrm{~mm}$ rainfall annually. Neea and Ticodendron trees were scarce and scattered around ca $4 \mathrm{~km}^{2}$ area. Ticodendron trees were large, often reaching the canopy whereas Neea pittieri individuals were small trees in the understory reaching up to $3 \mathrm{~m}$ in height. Host trees were determined with the help of the local expert Dr. Victor Madrigal Elizondo. Ticodendron incognitum individuals were determined based on tree stems and leafs using binoculars. All together 34 root samples were collected, including 15 individuals of Ticodendrum incognitum and 19 individuals of Neea pittieri across several square kilometers. In order to collect fine roots from each tree individual and ascertain host identity, main root was traced from the tree stem.

Soil samples were placed into plastic bags and processed within 24 hours after collection. Roots were carefully cleaned under tap water and placed into large Petri dishes filled with water. Only vital tree roots were processed. Ectomycorrhizal morphotypes were distinguished under stereomicroscope based on color and roughness of mantle, presence of emanating hyphae and rhizomorphs. If available, at least two EcM root tips from each morphotype per soil sample were stored in CTAB buffer (1\% cetyltrimethylammonium bromide, $100 \mathrm{mM}$ Tris-HCL (pH 8.0), $1.4 \mathrm{M}$ $\mathrm{NaCl}, 20 \mathrm{mM}$ ethylenediaminetetraacetic acid) for molecular analyses.

\section{Molecular and statistical analyses}

DNA was extracted from EcM root tips using Thermo Scientific Phire Plant Direct PCR Kit (Thermo Scientific, Waltham, MA, USA) according to the manufacturer's instructions. In the course of the study, PCR was performed by use of 5x HOT FIREPol Blend Master Mix Ready to Load (Solis BioDyne, Tartu, Estonia). In EcM root tips, fungal rDNA Internal Transcribed Spacer (ITS) region was amplified with a forward primer ITSOF (5`-acttggtcatttagaggaagt-3`) in 
combination with reverse primer LR0B(5'-acccgctgaacttaagc- $\left.3^{\prime}\right)$. In case of PCR failure we combined ITSOF with ITS2 (5'-gctgcgttcttcatcgatgc-3') and 58SF (5'- atgcatcgatgaagaacgc-3') with LR0B in order to amplify a shorter fragment of fungal DNA. PCR reactions were run under the following conditions: $95^{\circ} \mathrm{C}$ for $15 \mathrm{~min}$; five cycles of $42{ }^{\circ} \mathrm{C}$ for $30 \mathrm{~s}, 72{ }^{\circ} \mathrm{C}$ for $60 \mathrm{~s}$ and $92{ }^{\circ} \mathrm{C}$ for $45 \mathrm{~s} ; 35$ cycles of $65^{\circ} \mathrm{C}$ for $30 \mathrm{~s}, 72{ }^{\circ} \mathrm{C}$ for $60 \mathrm{~s}$ and $92{ }^{\circ} \mathrm{C}$ for $45 \mathrm{~s}$, followed by a final cycle of $65{ }^{\circ} \mathrm{C}$ for $30 \mathrm{~s}$ and $72{ }^{\circ} \mathrm{C}$ for $10 \mathrm{~min}$ for all primer combinations. PCR products were separated by electrophoresis through a $1.5 \%$ agarose gel in $0.5 \times$ TBE buffer $(45 \mathrm{mM}$ Tris Base, $45 \mathrm{mM}$ Boric Acid, $1 \mathrm{mM}$ EDTA (pH 8.0)), visualized under UV light and purified using Exo-Sap enzymes (Sigma, St. Louis, MO, USA).

Sequencing of fungal DNA was performed with primers ITS5 (5 -ggaagtaaaagtcgtaacaagg 3') and ITS4 (5'- tcctccgcttattgatatgc -3'). Sequences were assembled, checked, trimmed and manually corrected in Sequencher 4.10.1 software (GeneCodes Corp., Ann Arbor, MI, USA). Sequences were confirmed to belong to EcM fungal lineages (cf. Tedersoo et al. 2010) by use of BLASTn searches against the International Sequence Databases (INSD) or UNITE (Abarenkov et al. 2010).

In order to illustrate the presence of fungal mantle in $T$. incognitum root tips, $8 \mu \mathrm{m}$ cross sections were cut with a TBS Minotome Plus OM2563 microtome. Cross sections of roots were photographed with Nikon Eclipse 80i at 400-600x magnification (Fig. 1).

To estimate the relative importance of host effect to EcM community I applied multivariate analysis of variance as implemented in the adonis function of the Vegan package of R (Oksanen et al. 2007). For relevant illustration I constructed a nonmetric multidimensional scaling (NMDS) plot in ecodist package of R (Goslee \& Urban 2007).
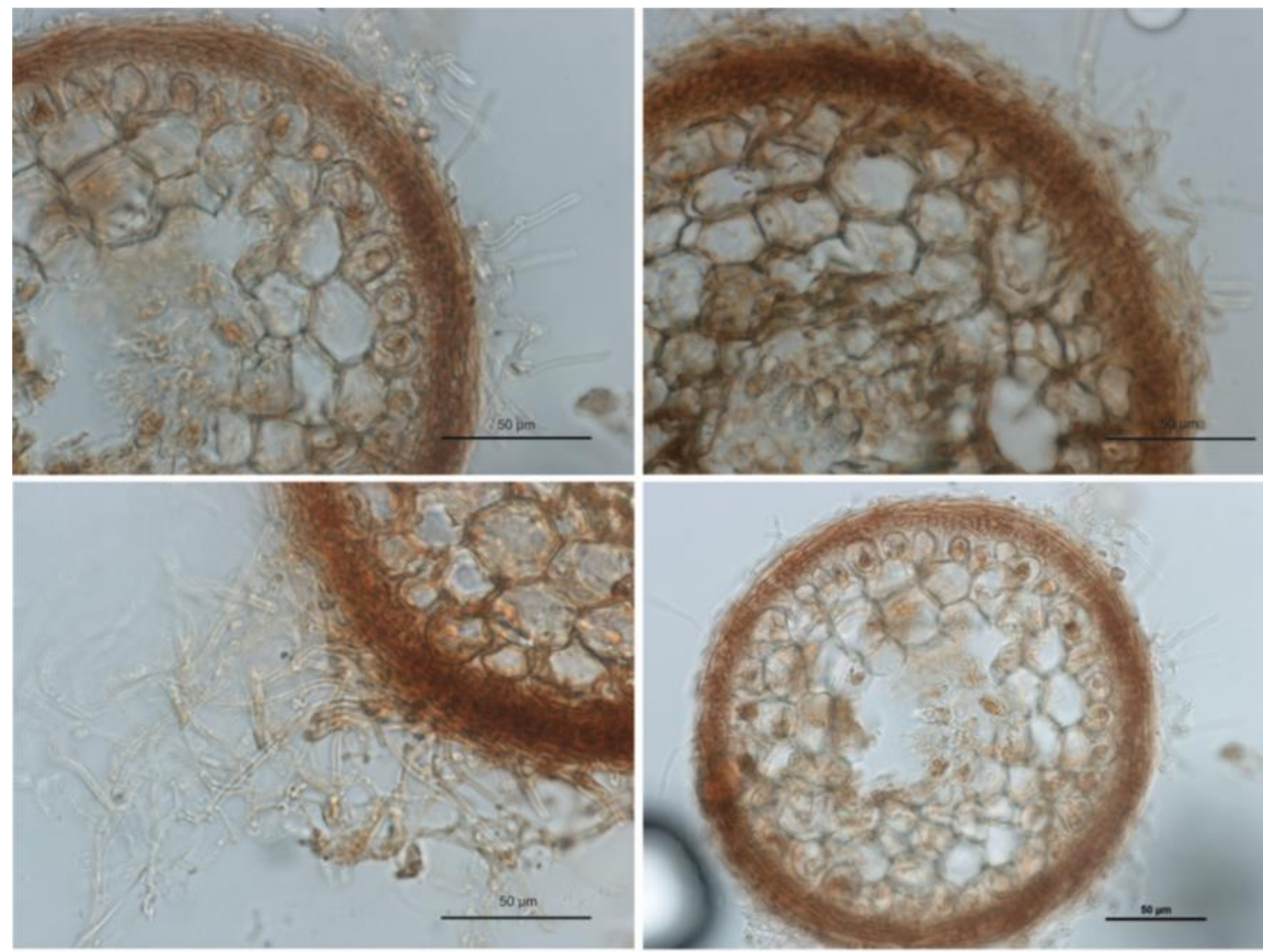

Fig. 1 - Light micrographs of Ticodendron incognitum root tip cross sections from UDB023273 (Boletales). Fungal mantle and hyphae are visible. Scale Bars: $50 \mu \mathrm{m}$. 


\section{Results}

In the course of the study $81 \mathrm{EcM}$ root tips were extracted. Thirty-eight EcM root tips were associated with Neea pittieri and 43 with Ticodendron incognitum. After DNA extraction, PCR and sequencing, $30(78.9 \%)$ of sequences associated with $N$. pittieri and $16(37.2 \%)$ associated with $T$. incognitum yielded high quality EcM fungal sequences.

Based on $97 \%$ similarity threshold we distinguished 14 EcM OTUs (Table 1). Ten OTUs were associated with Neea pittieri and five OTUs with Ticodendron incognitum. Most OTU rich ectomycorrhizal lineage was /tomentella-thelephora containing eight OTUs. Other lineages were represented with the following number of OTUs: /boletus (four), /pisolithus-scleroderma (one) and /inocybe (one). Latter two lineages were associated only with Neea pittieri. Only one fungal OTU was shared between two hosts. Accordingly, host effect was evident when tested with permutational anova $(\mathrm{R}=0.203 ; \mathrm{F}=5.63 ; \mathrm{P}=0.001$; Fig. 2). Four OTUs were found only once in the dataset (i.e. singletones), three of them were associated with $N$. pittieri and one with Ticodendron incognitum. Sequences from 11 OTUs clustered into Species Hypothesis (SH) with 97\% similarity threshold (Table 1). Five of SH-s were exclusively associated with $N$. pittieri. None of the SH associated with $T$. incognitum was exclusive. T. incognitum shared fungal SH-s with Oreomunnea mexicana root symbiont and with Tomentella fruitbodies collected beneath Neea and Coccoloba communities from Central America. The latter SH was shared also with Neea pittieri. Neea pittieri shared SH from /tomentella -thelephora lineage with Guapira macrocarpa from Mexico and /boletus SH with Pinus taeda from North Carolina.

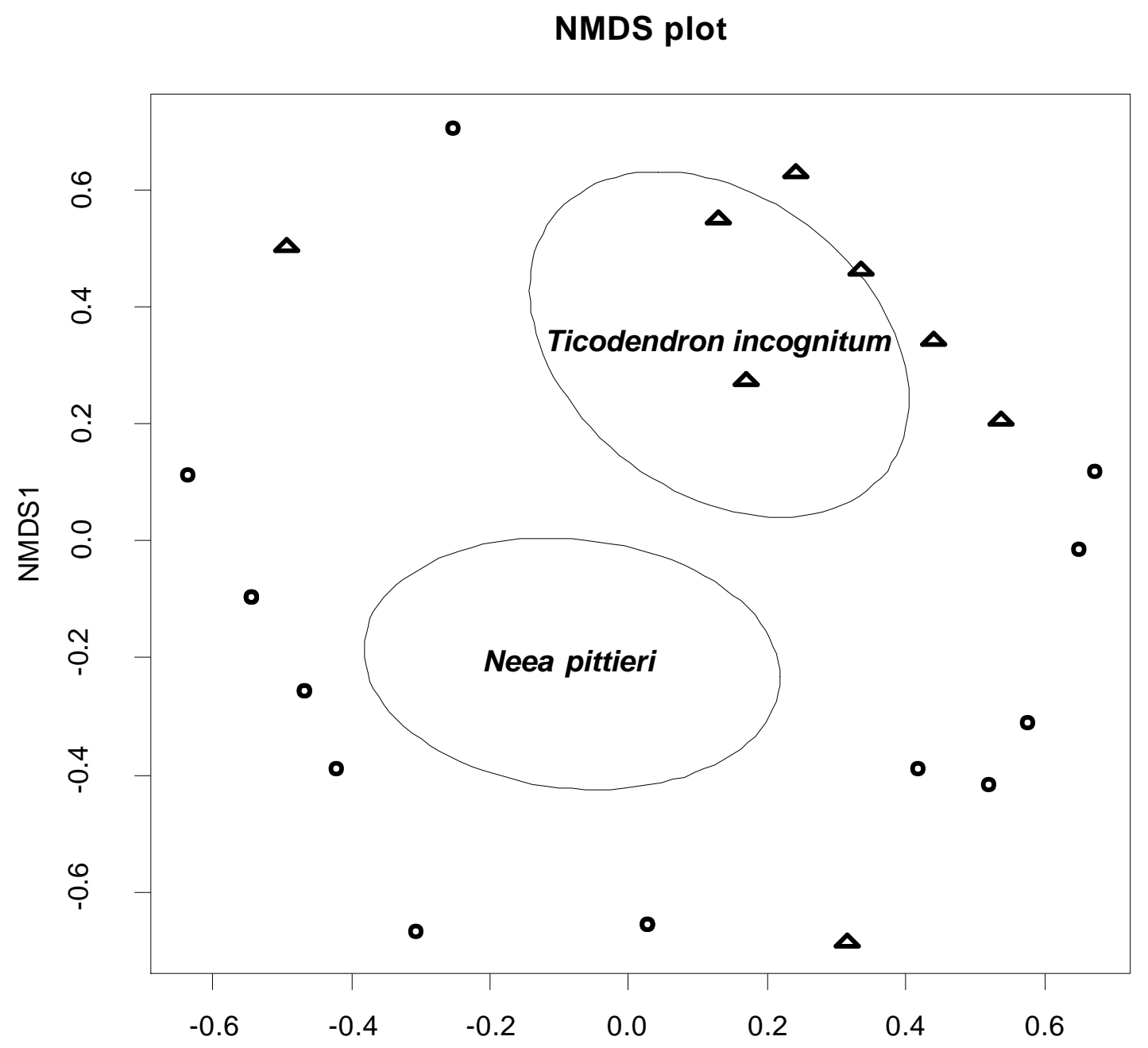

Fig. 2 - Nonmetric multidimensional scaling ordination plot with $95 \%$ confidence intervals demonstrating the Ticodendron incognitum (triangles) and Neea pittieri (circles) associated EcM fungal communities. 
Table 1 Distribution of fungal species hypothesis and OTUs at 97\% cutoff level, associating with Ticodendron incognitum and Neea pittieri individuals in Costa Rica forest. Asterisks denote species hypothesis that are exclusively associated with Neea pittieri.

\begin{tabular}{|c|c|c|c|c|c|c|c|c|}
\hline $\begin{array}{l}\text { EcM lineage } \\
\text { No. of sequences in SH } \\
\text { Species hypothesis }\end{array}$ & $\begin{array}{c}\text { /tomentella- } \\
\text { thelephora } \\
3 \\
\text { SH1190450.08* } \\
\end{array}$ & $\begin{array}{c}\text { /tomentella- } \\
\text { thelephora } \\
9 \\
\text { SH1140548.08* } \\
\end{array}$ & $\begin{array}{c}\text { /tomentella- } \\
\text { thelephora } \\
11 \\
\text { SH1140532.08 } \\
\end{array}$ & $\begin{array}{c}\text { /tomentella- } \\
\text { thelephora } \\
3 \\
\text { SH1140724.08* } \\
\end{array}$ & 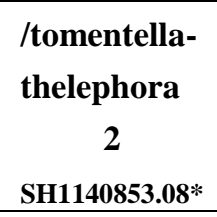 & $\begin{array}{l}\text { tomentella- } \\
\text { thelephora } \\
\quad 3 \\
\text { SH1140726.08* }\end{array}$ & $\begin{array}{c}\text { /tomentella- } \\
\text { thelephora } \\
2 \\
\text { SH1140821.08 } \\
\end{array}$ & $\begin{array}{c}\text { /tomentella- } \\
\text { thelephora } \\
2 \\
\text { SH1233043.08 } \\
\end{array}$ \\
\hline Neea pittieri & UDB023243 & & & & & & & \\
\hline Neea pittieri & & UDB023245 & & & UDB023246 I & 23247 & & \\
\hline Neea pittieri & UDB023250 & & & & & & & \\
\hline Neea pittieri & UDB023251 & & & & & & & \\
\hline \multicolumn{9}{|l|}{ Neea pittieri } \\
\hline Neea pittieri & & UDB023253 & 023262 & & & UDB023254 & & \\
\hline Neea pittieri & & & UDB023255 & & & & & \\
\hline Neea pittieri & & & & \multicolumn{2}{|c|}{ UDB023258 UDB023259 } & & & \\
\hline Neea pittieri & & UDB023260 & & & & UDB023261 & & \\
\hline Neea pittieri & & & & & & UDB023262 & & \\
\hline Neea pittieri & & & UDB023263 & & & & & \\
\hline Neea pittieri & & UDB023264 & 023265 & & & & & \\
\hline Neea pittieri & & & & UDB023266 & & & & \\
\hline Neea pittieri & & UDB023267 & & & & UDB23268 & & \\
\hline Neea pittieri & & UDB023269 & 023270 & & & & & \\
\hline Neea pittieri & & & & & UDB023271 & & UDB023272 & \\
\hline Ticodendron incognitum & & & UDB023274 & & & & & \\
\hline Ticodendron incognitum & & & & & & & & \\
\hline Ticodendron incognitum & & & UDB023276 & & & & & \\
\hline Ticodendron incognitum & & & & & & & & \\
\hline Ticodendron incognitum & & & & & & & & \\
\hline Ticodendron incognitum & & & & & & & & \\
\hline Ticodendron incognitum & & & & & & & & \\
\hline Ticodendron incognitum & & & & & & & & UDB023282 \\
\hline
\end{tabular}


Table 1 Continued.

\begin{tabular}{|c|c|c|c|c|c|c|}
\hline $\begin{array}{l}\text { EcM lineage } \\
\text { No. of sequences in } \\
\text { SH } \\
\text { Species hypothesis }\end{array}$ & $\begin{array}{l}\text { /boletus } \\
4 \\
4 \\
\text { SH1169225.08 } \\
\end{array}$ & $\begin{array}{l}\text { /boletus } \\
2 \\
2 \\
\text { SH1179911.08 } \\
\end{array}$ & /boletus & /boletus & $\begin{array}{l}\text { /pisolithus- } \\
\text { scleroderma }\end{array}$ & $\begin{array}{c}\text { /inocybe } \\
2 \\
\text { SH1213002.08 } \\
\end{array}$ \\
\hline Neea pittieri & UDB023244 & & & & & \\
\hline Neea pittieri & & & & & & \\
\hline Neea pittieri & & & & & & UDB23248 \\
\hline Neea pittieri & & & & & & \\
\hline Neea pittieri & & & & & UDB23249 & \\
\hline Neea pittieri & & & & & & \\
\hline Neea pittieri & & & & & & $\begin{array}{l}\text { UDB23256 } \\
\text { UDB023257 }\end{array}$ \\
\hline Neea pittieri & & & & & & \\
\hline Neea pittieri & & & & & & \\
\hline Neea pittieri & & & & & & \\
\hline Neea pittieri & & & & & & \\
\hline Neea pittieri & & & & & & \\
\hline Neea pittieri & & & & & & \\
\hline Neea pittieri & & & & & & \\
\hline Neea pittieri & & & & & & \\
\hline Neea pittieri & & & & & & \\
\hline Ticodendron incognitum & & UDB023273 & & UDB033271 & & \\
\hline Ticodendron incognitum & & & & UDB033272 & & \\
\hline Ticodendron incognitum & & UDB023275 & & & & \\
\hline Ticodendron incognitum & & UDB023277 & UDB023278 & & & \\
\hline Ticodendron incognitum & & & UDB023271 & UDB033273 & & \\
\hline Ticodendron incognitum & & & UDB023280 & UDB033275 & & \\
\hline Ticodendron incognitum & & UDB023281 & & UDB033276 & & \\
\hline Ticodendron incognitum & & & & & & \\
\hline
\end{tabular}




\section{Discussion}

To the best of my knowledge this is the first study assessing Ticodendron incognitum ectomycorrhizal status. Examination of T. incognitum roots confirmed the scarce association with EcM fungi that belonged mainly to /tomentella-thelephora and /boletus lineages, which are commonly ectomycorrhizal with Fagales host trees in temperate and montane tropical regions (Smith et al. 2007, Corrales et al. 2016). Previous studies have shown high variation of EcM diversity of neotropical communities which are sometimes comparable with temperate regions (Tedersoo et al. 2010, Smith et al. 2011, Henkel et al. 2012, Amadou et al. 2014, Séne et al. 2015, Corrales et al. 2016, Põlme et al. 2017). Although the presence of EcM root tips were scarce, suggesting low ecological importance, the overall low diversity and richness of EcM community in current study is partly attributable to limited sampling effort, rendering direct comparison between studies unreliable.

In spite of limited sampling effort, I found evidence of host preference of adjacent but phylogenetically distant hosts. Neea pittieri and Ticodendron incognitum harbored distinct fungal communities and shared only one fungal OTU. Current findings corroborate with Tedersoo et al. (2010) who reported low diversity and high host preference for dispersed, low density hosts from Polygonaceae and Nyctaginaceae in Ecuador. These authors hypothesized that isolated EcM host plants function as discrete habitat islands with limited photosynthetic resources and interconnectivity. Accordingly, studies from EcM dominated communities in neotropics report high EcM fungal diversity, suggesting that prevalence of suitable hosts enhances dispersal and resource availability being major driver of EcM fungal diversity (Smith et al. 2011, 2013, Corrales et al. 2016). The contrasts in observed host preference between studies could be partly ascribed to phylogenetic proximities of examined host species - Smith et al. (2011) sampled hosts from the same family, while Tedersoo et al. (2010) and present study addressed hosts from different families and orders, respectively. However, latter study by Smith et al. (2013) examining Pakaraimaea dipterocarpacea and Dicymbe jenmanii from different subclasses in nearby savanna ecosystem, documented moderate host effect suggesting its conditional nature.

Few non-exclusive EcM SHs associated with Ticodendron incognitum and Neea pittieri were distributed mainly in Central America, with one exception from North America. One of the SH associated with Ticodendron incognitum was shared with Oreomunnea mexicana (Juglandaceae) and mutual EcM symbiont of Ticodendron incognitum and Neea pittieri falls in the same SH with Tomentella fruitbodies found under mixed community of Coccoloba spp. and Neea spp. from Mexico. The overall high ratio of novel SH-s implicate that EcM communities in these regions remain understudied.

In spite of low sampling effort current results suggest that EcM association of Ticodendron incognitum are very moderate. It has been proposed that various taxa among Fagales have reduced or lost their ancestral capacity to form EcM, which has often been attributed to development of actinorrhizal symbiosis or shift to herbaceous life forms in other orders (Tedersoo \& Brundett 2017). Generalization about EcM biogeography predicts its lower ecological importance in tropical regions which has been attributed mainly to rapid turnover of organic matter and weak soil stratification (Tedersoo et al. 2012). I propose that inconsistent EcM root colonization of $T$. incognitum is a result of reduction of EcM habit with expansion to mid-elevation tropical habitats in Mesoamerica, compared to its temperate ancestors from Tertiary when many extant EcM groups of plants and fungi evolved (Hammel \& Burger 1991, Zanne et al. 2014).

In conclusion, this study confirms my hypothesis about concordance of the Ticodendron incognitum phylogenetic placement and its EcM habit. The low diversity and scarce EcM associations of $T$. incognitum and Neea pittieri corroborates host abundance theory (Tedersoo et al. 2010). However, additional sampling of adjacent populations would enable to make more confident generalizations about putative low ecological importance of EcM habit of these species in Central American forests. 


\section{Acknowledgements}

I thank Dr. Carlos Rojas for help with the sampling permits and Victor Madrigal Elizondo for assistance in the field. This study received funding from the Estonian Science Foundation (grants PUT1399, PUT1317 and IUT20-30).

\section{References}

Béreau M, Garbaye J. 1994 - First observations on the root morphology and symbioses of 21 major tree species in the primary tropical rain forest of French Guyana. Annals of Forest Science 51, 407-416.

Becker M. 1983 - Ectomycorrhizae on Shorea (Dipterocarpaceae) seedlings in a lowland Malaysian rainforest. Malay Forestry 46, 146-170.

Corrales A, Arnold AE, Ferrer A, Turner BL, Dalling JW. 2016 - Variation in ectomycorrhizal fungal communities associated with Oreomunnea mexicana (Juglandaceae) in a Neotropical montane forest. Mycorrhiza 26, 1-17.

Connell JH, Lowman MD. 1989 - Low-diversity tropical rain forests: some possible mechanisms for their existence. The American Naturalist 134, 88-119.

Amadou B, McGuire K, Diédhiou A, 2014 - Ectomycorrhizal symbioses in tropical and neotropical forests. CRC Press.

Gómez-Laurito J, Luis D, Gómez P. 1989 - Ticodendron: a new tree from Central America. Annals of Missouri Botanical Garden 76, 1148-1151.

Goslee SC, Urban DL. 2007 - The ecodist package for dissimilarity-based analysis of ecological data. J Stat Soft 22:1-19

Hammel B, Burger WG. 1991 - Neither oak nor alder, but nearly: the history of Ticodendraceae. Annals of Missouri Botanical Garden 78, 89-95.

Hart TB, Hart JA, Murphy PG. 1989 - Monodominant and species-rich forests in the humid tropics: causes for their co-occurrence. The American Naturalist 133,613-633.

Henkel TW, Terborgh J, Vilgalys RJ. 2002 - Ectomycorrhizal fungi and their leguminous hosts in the Pakaraima Mountains of Guyana. Mycological Research 106, 515-531.

Henkel T. 2003 - Monodominance in the ectomycorrhizal Dicymbe corymbosa (Caesalpiniaceae) from Guyana. Journal of Tropical Ecology 19, 417-437.

Henkel TW, Aime MC, Chin MM, Miller SL, Vilgalys R, Smith ME. 2012 - Ectomycorrhizal fungal sporocarp diversity and discovery of new taxa in Dicymbe monodominant forests of the Guiana Shield. Biodiversity and Conservation 21, 2195-2220.

Larson-Johnson K. 2016 - Phylogenetic investigation of the complex evolutionary history of dispersal mode and diversification rates across living and fossil Fagales. New Phytologist 209, 418-435.

Manchester SR. 2011 - Fruits of Ticodendraceae (Fagales) from the Eocene of Europe and North America. International Journal of Plant Science 172, 1179-1187.

McGuire KL. 2007 - Common ectomycorrhizal networks may maintain monodominance in a tropical rain forest. Ecology 88, 567-574.

Morris MH, Perez-Perez MA, Smith ME, Bledsoe CS. 2009 - Influence of host species on ectomycorrhizal communities associated with two co-occurring oaks (Quercus spp.) in a tropical cloud forest. FEMS Microbiology Ecology 69, 274-287.

Moyersoen B. 2006 - Pakaraimaea dipterocarpacea is ectomycorrhizal, indicating an ancient Gondwanaland origin for the ectomycorrhizal habit in Dipterocarpaceae. New Phytologist $172,753-62$.

Onguene NA, Kuyper TW. 2001 - Mycorrhizal associations in the rain forest of South Cameroon. Forest Ecology and Management 140, 277-287.

Oksanen J, Kindt R, Legendre P, O'Hara B et al. 2007 - The vegan package. Community ecology package. Available from http://vegan.r-forge.r-project.org/. 
Põlme S, Bahram M, Kõljalg U, Tedersoo L. 2017 - Biogeography and Specificity of Ectomycorrhizal Fungi of Coccoloba uvifera. In: Ecological Studies, Vol. 230, Leho Tedersoo (Eds): Biogeography of Mycorrhizal Symbiosis. Springer, 345-359.

Tedersoo L, Brundett MC. 2017 - Evolution of Ectomycorrhizal Symbiosis in Plants. In: Ecological Studies, Vol. 230, Leho Tedersoo (Eds): Biogeography of Mycorrhizal Symbiosis. Springer, 407-467.

Tedersoo L, Sadam A, Zambrano M, Valencia R, Bahram M. 2010 - Low diversity and high host preference of ectomycorrhizal fungi in Western Amazonia, a neotropical biodiversity hotspot. The ISME Journal 4, 465-471.

Tedersoo L, Bahram M, Toots M, Diedhiou AG et al. 2012 - Towards global patterns in the diversity and community structure of ectomycorrhizal fungi. Molecular Ecology 21, 4160 4170.

Séne S, Avril R, Chaintreuil C, Geoffroy A et al. 2015 - Ectomycorrhizal fungal communities of Coccoloba uvifera (L.) L. mature trees and seedlings in the neotropical coastal forests of Guadeloupe (Lesser Antilles). Mycorrhiza 25, 547-559.

Smith ME, Douhan GW, Rizzo DM. 2007 - Ectomycorrhizal community structure in a xeric Quercus woodland based on rDNA sequence analysis of sporocarps and pooled roots. New Phytologist 174, 847-863.

Smith ME, Henkel TW, Aime MC, Fremier AK, Vilgalys R. 2011 - Ectomycorrhizal fungal diversity and community structure on three co-occurring leguminous canopy tree species in a Neotropical rainforest. New Phytologist 192, 699-712.

Smith ME, Henkel TW, Uehling JK, Fremier AK et al. 2013 - The ectomycorrhizal fungal community in a Neotropical forest dominated by the endemic dipterocarp Pakaraimaea dipterocarpacea. PLoS one 8:e55160.

St John TV. 1980 - A survey of mycorrhizal infection in an Amazonian rain forest. Acta Amazonica 10, 527-533.

St John TV, Uhl C. 1983 - Mycorrhizae in the rainforest at San Carlos de Rio Negro, Venezuela. Acta Cientifica Venezolana 34, 233-237.

Weber G, Spaaij F, Gams W. 1994 - Ticogloea, a new genus of hyphomycetes from roots of Ticodendron incognitum from Costa Rica. Mycological Research 98, 660-664.

Zanne AE, Tank DC, Cornwell WK, Eastman JM et al. 2014 - Three keys to the radiation of angiosperms into freezing environments. Nature 506, 89-92. 